\title{
Article
}

\section{DNA transfer: The role of temperature and drying time}

van Oorschot, Roland A. H., McArdle, Roiseann, Goodwin, William H and Ballantyne, Kaye N.

Available at http://clok.uclan.ac.uk/13857/

van Oorschot, Roland A. H., McArdle, Roiseann, Goodwin, William H ORCID: 0000-0002-3632-3552 and Ballantyne, Kaye N. (2014) DNA transfer: The role of temperature and drying time. Legal Medicine, 16 (3). pp. 161-163. ISSN $1344-6223$

It is advisable to refer to the publisher's version if you intend to cite from the work. http://dx.doi.org/10.1016/j.legalmed.2014.01.005

For more information about UCLan's research in this area go to http://www.uclan.ac.uk/researchgroups/ and search for <name of research Group>.

For information about Research generally at UCLan please go to http://www.uclan.ac.uk/research/

All outputs in CLoK are protected by Intellectual Property Rights law, including Copyright law. Copyright, IPR and Moral Rights for the works on this site are retained by the individual authors and/or other copyright owners. Terms and conditions for use of this material are defined in the policies page.

\section{CLoK}

Central Lancashire online Knowledge www.clok.uclan.ac.uk

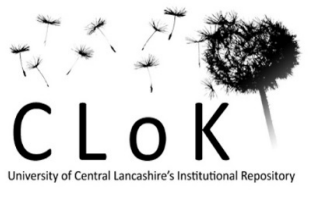




\section{Article}

\section{DNA transfer: The role of temperature and drying time}

van Oorshot, R.A.H., McArdle, R, Goodwin, William H and Ballantyne, K.N.

Available at http://clok.uclan.ac.uk/18050/

van Oorshot, R.A.H., McArdle, R, Goodwin, William H and Ballantyne, K.N. (2014) DNA

transfer: The role of temperature and drying time. Legal Medicine, 16 (3). pp. 161-163. ISSN

$1344-6223$

It is advisable to refer to the publisher's version if you intend to cite from the work.

http://dx.doi.org/10.1016/j.legalmed.2014.01.005

For more information about UCLan's research in this area go to

http://www.uclan.ac.uk/researchgroups/ and search for <name of research Group>.

For information about Research generally at UCLan please go to http://www.uclan.ac.uk/research/

All outputs in CLoK are protected by Intellectual Property Rights law, including Copyright law. Copyright, IPR and Moral Rights for the works on this site are retained by the individual authors and/or other copyright owners. Terms and conditions for use of this material are defined in the http://clok.uclan.ac.uk/policies/ 


\section{DNA transfer: The role of temperature and drying time}

Roland A.H. van Oorschot, Roiseann McArdle, William H. Goodwin, Kaye N. Ballantyne

\section{ABSTRACT}

It has previously been shown, and reconfirmed here, that biological material on a substrate will transfer readily upon contact with another substrate when wet but hardly when dry. There is however a paucity of data regarding the speed at which body fluids dry and how this may affect its transfer upon contact. Here we conduct transfer experiments at $4{ }^{\circ} \mathrm{C}, 22{ }^{\circ} \mathrm{C}$ and $40{ }^{\circ} \mathrm{C}$ at multiple time points during the drying process. The speed at which blood dries is dependent on the temperature and is generally dry within 30 to 60 min, quicker at higher temperature. The percentage of deposited DNA transferred upon contact follows an exponential pattern of decline from soon after deposition, decreasing until the sample is dry. There are no differences in transfer rates upon contact among the different temperature conditions within the first 5 min or after 60 min since deposit, but varies significantly between these time points. When considering the likelihood of a proposed scenario that incorporates one or more contact situations it is important to consider the timing of the potential transfer event(s) relative to when the biological sample in question was initially deposited. The results of this study will assist the interpretation and evaluation of alternative scenarios involving transfer of biological substances.

Keywords: 
DNA transfer; environmental conditions; trace DNA; forensic 


\section{Introduction}

Consideration of probability of human DNA containing material being transferred to other surfaces after initial deposit in different crime scene scenarios has been the subject of many criminal investigations and court proceedings. There have only been a few studies that have focussed on gaining insights into factors affecting such transfer events [1-4]. A recent review of current knowledge of DNA transfer and implications for casework by Meakin and Jamieson [5] clearly illustrates the need for a better understanding of DNA transfer.

Previous studies have demonstrated that transfer of body fluids from one surface to another is dependent on the dryness of the fluid at time of a transfer event $[1,4]$. Goray et al. [1] found that when the body fluid was wet on a hard non-porous substrate (plastic) 44-64\% was transferred to another substrate of the same type, and 97-100\% to soft porous substrate (cotton) depending on the manner of contact. When initially deposited on cotton far less DNA was transferred to the same substrate (0.14.3\%) or to plastic (0-3.1\%). However, when the body fluid was dried for $24 \mathrm{~h}$ prior to transfer events less DNA was transferred. Even though percentages of DNA transfer up to $44 \%$ were observed from dried blood between two hard non-porous surfaces when friction was applied, usually well below $1 \%$ transfer was observed, irrespective of the type of secondary substrate and manner of contact [1]. There is thus significantly less transfer when the sample is dry compared to when it is wet.

There is however little knowledge on how quickly biological fluids dry and what impact various levels of dryness may have on transfer. In order to assist evaluations of 
criminal offence scenarios, increased knowledge and data is necessary. While some will have a notion of the drying time of particular fluids it is useful to have a greater awareness of the approximate drying times of fluids and the impact different levels of dryness has on transfer. This is especially so for those that should consider such aspects during investigations of crime, when interpreting DNA profiles and when expert opinion is requested in court. An increased awareness will allow for more accurate assessment of proposed alternative scenarios that incorporate different sequences and timings of events. Here we report on a study which investigates the time required for blood to dry in different temperatures to the point that transfer is like that previously observed for samples dried for $24 \mathrm{~h}$ and how intermediate levels of dryness impact transfer. The impact of samples having dried for a longer period before a transfer event is also considered.

\section{Materials and Methods}

\subsection{Experimental design}

Aliquots of 15 or $30 \mu$ freshly acquired blood (collected in a lithium heparin tube), held briefly in a hand to approximate body temperature prior to spreading, were spread over a $1 \mathrm{~cm}^{2}$ area of plastic primary substrate. The blood was allowed to dry for a precise period of time, before the secondary substrate (cotton) was applied with pressured contact as described in $[1,4]$. Pressure was used during the contact stage between the primary and secondary substrates, to encourage transfer without variation caused by friction [1]. Blood was used as the biological source as it is one of the most frequently encountered body fluids in criminal offences. As the greatest transfer 
percentage of wet fluid observed by Goray et al [1] was when the primary deposit was plastic and the secondary substrate cotton this combination was applied in this investigation. The plastic and cotton are as used and described in previous studies $[1,4]$.

Preliminary investigations indicated that $15 \mu \mathrm{l}$ of blood spread over an area of approximately 1 x $1 \mathrm{~cm}$ appeared to dry within $15 \mathrm{~min}$ when on plastic and $25 \mathrm{~min}$ when on cotton (data not shown), so the majority (8x) of the13 time points tested were within the period 0 to 30 min inclusive. A time point of $24 \mathrm{~h}$ was included to have a comparison point with Goray et al [1]. Intermediate time points between predicted drying point and $24 \mathrm{~h}$ were included to cover potential transitional changes. A time point of 1 wk was also included to assess if longer drying time would impact the dryness of the blood on the substrate and consequently its rate of transfer. The time periods tested were 0, $2.5 \mathrm{~min} .5 \mathrm{~min} .7 .5 \mathrm{~min} .10 \mathrm{~min}, 15 \mathrm{~min}, 20 \mathrm{~min}, 30 \mathrm{~min}, 45$ min, 1 h, 4 h, $24 \mathrm{~h}$ and $1 \mathrm{wk}$.

These samples were prepared and the subsequent transfer experiments conducted in three different controlled temperature environments: hot ( $40{ }^{\circ} \mathrm{C}, \sim 40 \%$ humidity), room temperature $\left(22{ }^{\circ} \mathrm{C}, \sim 60 \%\right.$ humidity) and cold $\left(4{ }^{\circ} \mathrm{C}, \sim 60 \%\right.$ humidity). Tests were performed in all environments using $15 \mu \mathrm{l}$. Tests using $30 \mu \mathrm{l}$ were only performed at room temperature. Four replicates were performed of each sample/time/environment combination tested.

\subsection{DNA extraction, quantitation and genotyping}


Substrate samples of $1 \mathrm{~cm}^{2}$ plus a surrounding $0.3 \mathrm{~cm}$ margin were cut into smaller pieces $\left(\sim 0.3 \mathrm{~cm}^{2}\right)$ and extracted using the DNA IQ ${ }^{\mathrm{TM}}$ according to the manufacturer's protocol (Promega, USA) system on a Biomek ${ }^{\circledR}$ Nxp liquid handling workstation (Beckman Coulter, USA), with a final elution volume of DNA in the kit's elution buffer of $50 \mu l$. The extracted DNA was quantitated using Quantifiler ${ }^{\mathrm{TM}}$ (Life Technologies, USA) and an AB 7500 Real-Time PCR instrument (Life Technologies, USA) according to manufacturer's recommendations.

A selection of samples were amplified with a maximum of $10 \mu \mathrm{l}$ or $1 \mathrm{ng}$ input DNA using half-volume AmpFlSTR ${ }^{\circledR}$ Profiler Plus ${ }^{\mathrm{TM}}$ (Life Technologies, USA) on a 3100 Genetic Analyser (Life Technologies, USA) and analysed using GeneMapper ${ }^{\circledR}$ ID v3.2 (Applied Biosystems, USA) according to manufacturer recommendations.

\subsection{Quality control}

Negative substrate control samples were taken from the primary and secondary substrates per set of repeats for each combination of variables at the time of each transfer test (same size as and just adjacent to test samples). DNA was extracted from all of these and amplified for Profiler Plus typing. No alleles were detected on any of these substrate samples. Furthermore two secondary substrate samples produced after transfer at a stage when the blood on the primary substrate was assumed to have been dry, but from which relatively high amounts of DNA were extracted, were profiled using Profiler Plus to check that the origin of the detected DNA was indeed from the expected source and not from a contamination event. The results indicate that the DNA was indeed only from the expected source. 


\subsection{Data analyses}

No substrate extraction or sample amount correction factor, as had been recommended by Verdon et al. [4] was required for the experimental design employed here. Empirical testing of 1,5,15 and $30 \mu \mathrm{l}$ dried blood showed no significant differences in DNA retrieval per $\mu$ l of blood from primary (plastic) and secondary (cotton with plastic backing) substrates (data not shown). Transfer percentages were calculated as the amount of DNA recovered from the secondary substrate / the total amount of DNA (primary + secondary substrates) recovered [4]. Statistical comparisons were performed with SPSS v17.0 (SPSS Inc.) using linear mixed model analysis, on log transfer rates. Model estimation was performed with the restricted maximum likelihood method with 10,000 iterations, with total DNA yield of each sample included as a random covariate to encompass potential sampling variation or loss. Exponential decay modelling was performed with GraphPad Prism v6.0 (GraphPad Software, USA).

\section{Results and Discussion}

The rates of transfer for all temperatures and volumes (Supplementary Table 1) followed a classic exponential decay pattern (Figure 1), with fairly constant rates of transfer initially, followed by sharp declines until the rate of transfer approached zero. There were no significant differences in transfer percentages between any conditions in the first 5 min (all p values $>0.05$ ) and after 60 min (all p values $>0.05$ ) since 
deposit. It has previously been observed by others $[1,4]$ that transfer occurs readily when fluids are wet, and to a very limited extent when dry. We can therefore use the point at which transfer rates are close to 0 as the point at which the blood used in the current experiment dried completely. The temperature at which the blood was deposited/dried had a significant effect on transfer over time, and therefore rate of drying $\left(F_{152}^{2}=4.639, \mathrm{p}=0.011\right)$. The blood dried significantly more slowly at cold temperatures compared to room $(p=0.009)$ and hot $(p=0.029)$, while there was no significant difference between room and hot temperatures when the volume of blood deposited remained constant $(\mathrm{p}=0.205)$. The mean transfer half-life, $\mathrm{t}^{\frac{1}{2}}$, defined as the length of time taken for transfer rates to decrease by $50 \%$ from their initial value $\left(\mathrm{t} 2=\frac{\ln 2}{\lambda}\right.$, where $\lambda$ is the decay constant, or the rate of decrease in transfer over time) decreases by approximately $50 \%$ for every $20^{\circ} \mathrm{C}$ increase in temperature - thus transfer, under the experimental conditions described here, will have a half-life of $19.7 \min (95 \%$ confidence interval $13.5-36.1 \mathrm{~min})$ at $4{ }^{\circ} \mathrm{C}, 8.3 \mathrm{~min}(6.2-12.7)$ at 22 ${ }^{\circ} \mathrm{C}$, and $4.2 \min (2.8-8.1)$ at $40{ }^{\circ} \mathrm{C}$.

As the initial observed levels of transfer from $15 \mu \mathrm{l}$ deposits were similar for all temperature conditions (averages $56.73 \%$ for cold, $55.73 \%$ of room temperature, and 61.14\% for hot, all pairwise comparisons $\mathrm{p}>0.05$ ), the difference in half-life ensures that the time at which transfer is $<1 \%$ is significantly different for each temperature. Transfer will effectively cease through sample drying in cold conditions after $41 \mathrm{~min}$ as modelled from the decay curve, although it first decreased below $1 \%$ only at 60 min in the experimental data. At room temperature, it will take $22 \mathrm{~min}$ (30 min experimentally) and only $13 \mathrm{~min}$ at $40^{\circ} \mathrm{C}$ (15 min experimentally). 
Increasing the volume from $15 \mu \mathrm{l}$ to $30 \mu \mathrm{l}$ at room temperature increased the amount of DNA transferred by an average of 3.59\% across time points, although not to a significant degree $\left(F_{153}^{1}=2.80, \mathrm{p}=0.097\right)$. As the area in which the blood was deposited remained constant $\left(1 \mathrm{~cm}^{2}\right)$, it is likely that the increased volume caused a decreased rate of drying, with $30 \mu \mathrm{l}$ showing a slightly increased half-life compared to $15 \mu \mathrm{l}$ (8.6 min compared to $8.3 \mathrm{~min}$ ), and an additional 9 minutes until complete drying (i.e. the time point when the curve becomes horizontal in Figure 1) (95\% confidence intervals 54.1 - 73.1 min to complete drying for $15 \mu \mathrm{l}$, and 63.1-81.7 min for $30 \mu \mathrm{l})$. Further investigations would be needed to determine if other volumes show the same trend. For example a large pool of blood may show a very different decay profile.

Significant interactions were observed between the temperature and time $\left(F_{152}^{22}=3.950, \mathrm{p}=2.2 \times 10^{-7}\right)$. As the volume was only tested at one temperature, it was not possible to determine if there was an interaction between volume and time, or all three conditions, although it seems likely that this would occur. This introduces additional complications when estimating the possibility of transfer occurring in an unknown stain, as potentially all three variables (time between contact, ambient temperature and volume of blood deposited) must be inferred. Differences in humidity are likely to also influence drying time and should be investigated and potentially considered as an additional variable when estimating transfer.

It should be noted that although transfer rates were relatively static post-drying for all temperatures, flaking of dried blood deposits on the plastic were observed, especially for $30 \mu \mathrm{l}$ deposits, which may have contributed to some of the variation observed at these time points (see Figure 1). The variation in transfer observed when blood dried 
on plastic was transferred to cotton during pressure contact has also been noted by others [1]. Both Goray et al [1] and Verdon et al [4] comment on observing powdering and flaking of dried blood on hard substrates and indicate that this phenomenon could affect transfer and yields=

Whilst the major difference in transfer percentage between fresh and dry deposits concur with the general findings of others $[1,4]$ the overall transfer percentage observed in this study upon contact immediately after deposit (61\%) was lower than expected based on observations in a similar situation by others (90\%) [1]. The reason for this is unclear but may in part be due to differences in the batches of substrates used and/or differences in DNA extraction methods utilised. The type of substrates involved in a contact event can significantly influence the percentage of biological material transferred [4] and the quantity of DNA retrieved from substrates can be dependent on the DNA extraction methods applied [6].

The current study used plastic as the primary substrate on which blood was deposited. Preliminary investigations indicated that blood appeared to dry faster on this substrate than on cotton, which suggests a further variable, substrate, will need to be investigated. However, our data indicate that the transfer will follow an exponential decay pattern, and differences at any one time point likely to dissipate within $60 \mathrm{~min}$, or as soon as the relevant deposit is dry.

Here we have investigated the drying time of blood that had been collected in a tube with an anticoagulant. The drying time of fresh untreated blood and other body fluids 
such as semen and saliva may be different and should be the subject of further investigations.

\section{Conclusions}

Blood dries within a relatively short period. The speed at which it dries is dependent on temperature and is slower in colder conditions. Transfer of DNA upon contact depends significantly on the dryness of the biological material being transferred. When considering the likelihood of a proposed scenario that incorporates one or more contact situations it is important to consider the timing of the potential transfer event(s) relative to when the biological sample in question was initially deposited.

\section{Acknowledgements}

We would like to thank Robert Howie, Adam Poy, Mariya Goray, Tim Verdon and Annalisa Durdle for their assistance with conducting this investigation. 


\section{References}

1. M. Goray, E. Eken, R.J. Mitchell, R.A.H. van Oorschot, Secondary DNA transfer of biological substances under varying test conditions, Forensic Sci. Int. Genet. 4 (2010) 62-67.

2. M. Goray, R.J. Mitchell, R.A.H. van Oorschot, Investigation of secondary DNA transfer of skin cells under controlled test conditions, Leg. Med 12 (2010) 117-120.

3. P. Wiegand, C Heimbold, R. Klein, U. Immel, D. Stiller, M. Klintschar, Transfer of biological stains from different surfaces, Int. J. Legal Med. 125 (2011) 727-731.

4. T.J. Verdon, R.J. Mitchell, R.A.H. van Oorschot, The influence of substrate on DNA transfer and extraction efficiency, Forensic Sci. Int. Genet. 7 (2013) 167-175.

5. G. Meakin, A. Jamieson, DNA transfer: review and implications for casework, Forensic Sci. Int. Genet. 7 (2013) 434-443.

6. T.J. Verdon, R.J. Mitchell, R.A.H. van Oorschot, Evaluating the efficiency of DNA extraction methods from different substrates, Forensic Sci. Int. Genet. Suppl. Ser. 3 (2011) e93-e94. 


\section{Figure titles:}

Fig. 1. Exponential decay profile of percentage DNA transfer of 15 or $30 \mu \mathrm{l}$ of blood deposited on plastic at different temperatures and left to dry for different duratons before transfering to cotton. (The average percentage transfer of DNA, with standard deviation, at each time point, is available in Supplementary Table 1) 
Supplementary Data

\begin{tabular}{|c|c|c|c|c|}
\hline $\begin{array}{l}\text { Temperatur } \\
\text { e }\end{array}$ & $\begin{array}{l}\text { Volume } \\
\text { ( } \mu \mathrm{l})\end{array}$ & $\begin{array}{l}\text { Time } \\
\text { (min) }\end{array}$ & $\begin{array}{l}\text { Transfer } \\
\text { Percentage }\end{array}$ & $\begin{array}{l}\text { Total DNA Yield } \\
\text { (ng) }\end{array}$ \\
\hline \multirow{4}{*}{ Cold } & \multirow{4}{*}{15} & \multirow{4}{*}{0} & 64.05 & 110.9 \\
\hline & & & 60.15 & 130.5 \\
\hline & & & 54.79 & 146.0 \\
\hline & & & 47.91 & 102.7 \\
\hline \multirow{4}{*}{ Cold } & \multirow{4}{*}{15} & \multirow{4}{*}{2.5} & 65.79 & 152.0 \\
\hline & & & 51.80 & 111.0 \\
\hline & & & 52.25 & 111.0 \\
\hline & & & 56.01 & 145.5 \\
\hline \multirow{4}{*}{ Cold } & \multirow{4}{*}{15} & \multirow{4}{*}{5} & 43.88 & 216.5 \\
\hline & & & 52.94 & 153.0 \\
\hline & & & 59.30 & 142.5 \\
\hline & & & 75.11 & 82.6 \\
\hline \multirow{4}{*}{ Cold } & \multirow{4}{*}{15} & \multirow{4}{*}{7.5} & 68.09 & 258.5 \\
\hline & & & 71.32 & 197.0 \\
\hline & & & 43.17 & 104.7 \\
\hline & & & 64.48 & 167.5 \\
\hline \multirow{4}{*}{ Cold } & \multirow{4}{*}{15} & \multirow{4}{*}{10} & 72.83 & 109.9 \\
\hline & & & 48.10 & 249.5 \\
\hline & & & 29.76 & 150.2 \\
\hline & & & 15.39 & 37.4 \\
\hline Cold & 15 & 15 & 61.54 & 208.0 \\
\hline
\end{tabular}




\begin{tabular}{|c|c|c|c|c|}
\hline & & & 22.94 & 190.8 \\
\hline & & & 42.76 & 148.5 \\
\hline & & & 33.13 & 166.0 \\
\hline & & & 38.08 & 239.0 \\
\hline & & & 27.56 & 190.5 \\
\hline Cou & & & 27.20 & 198.5 \\
\hline & & & 38.49 & 245.5 \\
\hline & & & 13.06 & 209.4 \\
\hline & & & 23.44 & 188.1 \\
\hline & & & 27.07 & 152.2 \\
\hline & & & 13.63 & 298.2 \\
\hline & & & 20.41 & 236.2 \\
\hline & & & 13.26 & 212.7 \\
\hline tou & & & 10.99 & 323.0 \\
\hline & & & 8.35 & 216.1 \\
\hline & & & 0.02 & 289.1 \\
\hline & $1 \Gamma$ & $c 0$ & 0.00 & 212.0 \\
\hline tou & 10 & & 0.00 & 234.0 \\
\hline & & & 0.00 & 456.0 \\
\hline & & & 0.08 & 271.2 \\
\hline & & & 16.35 & 17.1 \\
\hline Cora & 10 & 240 & 0.00 & 329.5 \\
\hline & & & 0.00 & 363.0 \\
\hline Cold & 15 & 2400 & 0.00 & 231.0 \\
\hline
\end{tabular}




\begin{tabular}{|c|c|c|c|c|}
\hline & & & 0.00 & 400.5 \\
\hline & & & 1.38 & 227.7 \\
\hline & & & 0.00 & 273.5 \\
\hline & & & 67.69 & 91.6 \\
\hline & & & 69.10 & 212.0 \\
\hline Hou & & & 78.86 & 186.4 \\
\hline & & & 28.90 & 141.4 \\
\hline & & & 55.86 & 145.0 \\
\hline & & & 46.12 & 129.0 \\
\hline & & & 52.70 & 204.0 \\
\hline & & & 58.27 & 139.0 \\
\hline & & & 28.10 & 121.0 \\
\hline & & & 56.17 & 162.0 \\
\hline & & & $\begin{array}{l}42.53 \\
\end{array}$ & 154.0 \\
\hline & & & 21.10 & 152.1 \\
\hline & & & 17.16 & 178.1 \\
\hline Hot & 15 & 75 & 19.45 & 251.4 \\
\hline & & & 19.28 & 136.9 \\
\hline & & & 28.06 & 265.5 \\
\hline & & & 4.85 & 287.5 \\
\hline & & & 9.93 & 244.3 \\
\hline Hou & 15 & 10 & 26.57 & 157.3 \\
\hline & & & 8.56 & 280.5 \\
\hline Hot & 15 & 15 & 0.00 & 211.5 \\
\hline
\end{tabular}




\begin{tabular}{|c|c|c|c|c|}
\hline & & & 0.00 & 262.5 \\
\hline & & & 0.00 & 215.5 \\
\hline & & & 0.11 & 245.3 \\
\hline & & & 1.23 & 303.2 \\
\hline & & & 1.36 & 215.9 \\
\hline Hou & & & 0.00 & 225.5 \\
\hline & & & 0.00 & 293.0 \\
\hline & & & 0.00 & 227.0 \\
\hline & & & 0.03 & 258.6 \\
\hline & & & 0.04 & 128.5 \\
\hline & & & 2.35 & 225.8 \\
\hline & & & 0.69 & 277.9 \\
\hline & & & 1.63 & 245.5 \\
\hline & & & 0.03 & 299.1 \\
\hline & & & 0.98 & 188.8 \\
\hline & & & 0.12 & 111.6 \\
\hline & & & 0.00 & 199.0 \\
\hline Hor & 15 & & 0.03 & 145.0 \\
\hline & & & 23.35 & 227.0 \\
\hline & & & 0.00 & 187.0 \\
\hline & & & 1.88 & 281.8 \\
\hline Hot & 15 & 240 & 68.58 & 67.8 \\
\hline & & & 2.16 & 240.2 \\
\hline Hot & 15 & 2400 & 0.03 & 204.6 \\
\hline
\end{tabular}




\begin{tabular}{|c|c|c|c|c|}
\hline & & & 0.00 & 308.0 \\
\hline & & & 11.44 & 125.9 \\
\hline & & & 0.05 & 183.1 \\
\hline & & & 5.77 & 182.0 \\
\hline & & & 0.00 & 202.0 \\
\hline Hou & & & 1.84 & 326.5 \\
\hline & & & 0.00 & 205.0 \\
\hline & & & 44.49 & 84.0 \\
\hline Room & & & 72.59 & 59.1 \\
\hline Temp. & & & 30.95 & 36.4 \\
\hline & & & 74.90 & 150.2 \\
\hline & & & 57.93 & 73.1 \\
\hline Room & & & 45.14 & 58.7 \\
\hline Temp. & & & 54.23 & 130.0 \\
\hline & & & 72.43 & 142.2 \\
\hline & & & 34.95 & 62.8 \\
\hline Room & & & 35.34 & 101.3 \\
\hline Temp. & 15 & 5 & 35.68 & 98.0 \\
\hline & & & 48.94 & 117.5 \\
\hline & & & 53.21 & 70.1 \\
\hline Room & & & $\begin{array}{l}51.48 \\
\end{array}$ & 118.5 \\
\hline Temp. & 15 & 7.5 & 5.25 & 25.0 \\
\hline & & & $\begin{array}{ll}60.13 \\
\end{array}$ & 150.5 \\
\hline Room & 15 & 10 & $\begin{array}{l}21.98 \\
\end{array}$ & 87.8 \\
\hline
\end{tabular}




\begin{tabular}{|c|c|c|c|c|}
\hline \multirow[t]{3}{*}{ Temp. } & & & 40.13 & 104.4 \\
\hline & & & 36.08 & 108.0 \\
\hline & & & 0.04 & 40.1 \\
\hline \multirow{4}{*}{$\begin{array}{l}\text { Room } \\
\text { Temp. }\end{array}$} & \multirow{4}{*}{15} & \multirow{4}{*}{15} & 4.26 & 218.3 \\
\hline & & & 20.65 & 206.1 \\
\hline & & & 29.16 & 78.4 \\
\hline & & & 14.47 & 119.3 \\
\hline \multirow{4}{*}{$\begin{array}{l}\text { Room } \\
\text { Temp. }\end{array}$} & \multirow{4}{*}{15} & \multirow{4}{*}{20} & 0.05 & 186.1 \\
\hline & & & 0.08 & 120.1 \\
\hline & & & 13.47 & 151.4 \\
\hline & & & 7.71 & 131.7 \\
\hline \multirow{4}{*}{$\begin{array}{l}\text { Room } \\
\text { Temp. }\end{array}$} & \multirow{4}{*}{15} & \multirow{4}{*}{30} & 1.09 & 85.9 \\
\hline & & & 0.00 & 44.1 \\
\hline & & & 0.11 & 46.3 \\
\hline & & & 0.00 & 68.5 \\
\hline \multirow{4}{*}{$\begin{array}{l}\text { Room } \\
\text { Temp. }\end{array}$} & \multirow{4}{*}{15} & \multirow{4}{*}{45} & 0.87 & 52.0 \\
\hline & & & 0.91 & 99.4 \\
\hline & & & 1.06 & 42.6 \\
\hline & & & 0.22 & 113.8 \\
\hline \multirow{4}{*}{$\begin{array}{l}\text { Room } \\
\text { Temp. }\end{array}$} & \multirow{4}{*}{15} & \multirow{4}{*}{60} & 0.61 & 19.5 \\
\hline & & & 1.78 & 30.5 \\
\hline & & & 2.27 & 19.3 \\
\hline & & & 0.00 & 4.0 \\
\hline Room & 15 & 240 & 0.00 & 5.8 \\
\hline
\end{tabular}




\begin{tabular}{|c|c|c|c|c|}
\hline \multirow[t]{3}{*}{ Temp. } & & & 0.12 & 28.2 \\
\hline & & & 0.00 & 31.1 \\
\hline & & & 0.65 & 21.7 \\
\hline \multirow{4}{*}{$\begin{array}{l}\text { Room } \\
\text { Temp. }\end{array}$} & \multirow{4}{*}{15} & \multirow{4}{*}{2400} & 0.11 & 63.6 \\
\hline & & & 0.00 & 87.0 \\
\hline & & & 0.06 & 82.0 \\
\hline & & & 0.22 & 56.1 \\
\hline \multirow{4}{*}{$\begin{array}{l}\text { Room } \\
\text { Temp. }\end{array}$} & \multirow{4}{*}{15} & \multirow{4}{*}{10080} & 0.00 & 73.5 \\
\hline & & & 0.78 & 205.6 \\
\hline & & & 0.00 & 41.1 \\
\hline & & & 0.00 & 60.0 \\
\hline \multirow{4}{*}{$\begin{array}{l}\text { Room } \\
\text { Temp. }\end{array}$} & \multirow{4}{*}{30} & \multirow{4}{*}{0} & 81.69 & 116.9 \\
\hline & & & 60.12 & 124.8 \\
\hline & & & 69.03 & 149.2 \\
\hline & & & 72.83 & 144.9 \\
\hline \multirow{4}{*}{$\begin{array}{l}\text { Room } \\
\text { Temp. }\end{array}$} & \multirow{4}{*}{30} & \multirow{4}{*}{2.5} & 51.67 & 134.5 \\
\hline & & & $\begin{array}{l}73.63 \\
\end{array}$ & 146.0 \\
\hline & & & 68.75 & 134.6 \\
\hline & & & 57.31 & 126.5 \\
\hline \multirow{4}{*}{$\begin{array}{l}\text { Room } \\
\text { Temp. }\end{array}$} & \multirow{4}{*}{30} & \multirow{4}{*}{5} & 70.11 & 174.0 \\
\hline & & & 16.80 & 64.9 \\
\hline & & & 59.12 & 137.0 \\
\hline & & & 68.04 & 194.0 \\
\hline Room & 30 & 7.5 & 51.08 & 67.1 \\
\hline
\end{tabular}




\begin{tabular}{|c|c|c|c|c|}
\hline \multirow[t]{3}{*}{ Temp. } & & & 48.47 & 114.5 \\
\hline & & & 41.35 & $\begin{array}{ll}66.8 \\
\end{array}$ \\
\hline & & & 55.31 & 87.2 \\
\hline \multirow{4}{*}{$\begin{array}{l}\text { Room } \\
\text { Temp. }\end{array}$} & \multirow{4}{*}{30} & \multirow{4}{*}{10} & 33.33 & 87.8 \\
\hline & & & 36.82 & 138.5 \\
\hline & & & 36.50 & 168.5 \\
\hline & & & 32.47 & 142.9 \\
\hline \multirow{4}{*}{$\begin{array}{l}\text { Room } \\
\text { Temp. }\end{array}$} & \multirow{4}{*}{30} & \multirow{4}{*}{15} & 11.48 & 97.2 \\
\hline & & & 22.80 & 126.3 \\
\hline & & & 14.73 & 66.9 \\
\hline & & & 37.50 & 168.0 \\
\hline \multirow{4}{*}{$\begin{array}{l}\text { Room } \\
\text { Temp. }\end{array}$} & \multirow{4}{*}{30} & \multirow{4}{*}{20} & 12.91 & 110.8 \\
\hline & & & 0.00 & 191.5 \\
\hline & & & 15.97 & 113.7 \\
\hline & & & 32.37 & 156.0 \\
\hline \multirow{4}{*}{$\begin{array}{l}\text { Room } \\
\text { Temp. }\end{array}$} & \multirow{4}{*}{30} & \multirow{4}{*}{30} & 5.30 & 106.7 \\
\hline & & & 0.04 & 137.6 \\
\hline & & & 0.20 & 208.4 \\
\hline & & & 19.35 & 127.1 \\
\hline \multirow{4}{*}{$\begin{array}{l}\text { Room } \\
\text { Temp. }\end{array}$} & \multirow{4}{*}{30} & \multirow{4}{*}{45} & 1.65 & 68.6 \\
\hline & & & 3.54 & 98.0 \\
\hline & & & 3.89 & 58.8 \\
\hline & & & 3.34 & 65.2 \\
\hline Room & 30 & 60 & 1.28 & 35.6 \\
\hline
\end{tabular}




\begin{tabular}{|c|c|c|c|c|}
\hline \multirow[t]{3}{*}{ Temp. } & & & 0.18 & 31.8 \\
\hline & & & 1.94 & 10.4 \\
\hline & & & 0.15 & 39.9 \\
\hline \multirow{3}{*}{ Room } & \multirow{4}{*}{30} & \multirow{4}{*}{240} & 0.00 & 33.3 \\
\hline & & & 0.00 & 147.0 \\
\hline & & & 0.00 & 40.6 \\
\hline Temp. & & & 0.13 & 93.6 \\
\hline \multirow{4}{*}{$\begin{array}{l}\text { Room } \\
\text { Temp. }\end{array}$} & \multirow{4}{*}{30} & \multirow{4}{*}{2400} & 0.18 & 64.6 \\
\hline & & & 50.32 & 31.0 \\
\hline & & & 0.93 & 111.0 \\
\hline & & & 5.00 & 35.3 \\
\hline \multirow{4}{*}{ Room } & \multirow{4}{*}{30} & \multirow{4}{*}{10080} & 0.75 & 93.2 \\
\hline & & & 0.35 & 223.8 \\
\hline & & & 5.41 & 47.6 \\
\hline & & & 0.23 & 217.5 \\
\hline
\end{tabular}

